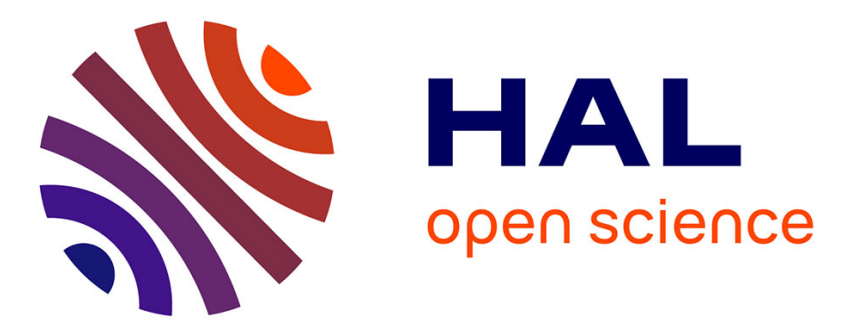

\title{
New geomorphic criteria on lateral propagation of blind thrust-related fold growth accommodating oblique convergence
}

\author{
Bernard Delcaillau, Jean-Michel Carozza, E. Laville, M. Amrhar, R.
}

Sheikholeslami

\section{To cite this version:}

Bernard Delcaillau, Jean-Michel Carozza, E. Laville, M. Amrhar, R. Sheikholeslami. New geomorphic criteria on lateral propagation of blind thrust-related fold growth accommodating oblique convergence. Annales de Géomorphologie / Annals of Geomorphology / Zeitschrift für Geomorphologie, 2007, 51 (2), pp.141-163. 10.1127/0372-8854/2007/0051-0141 . halshs-01066109

\section{HAL Id: halshs-01066109 \\ https://shs.hal.science/halshs-01066109}

Submitted on 19 Sep 2014

HAL is a multi-disciplinary open access archive for the deposit and dissemination of scientific research documents, whether they are published or not. The documents may come from teaching and research institutions in France or abroad, or from public or private research centers.
L'archive ouverte pluridisciplinaire HAL, est destinée au dépôt et à la diffusion de documents scientifiques de niveau recherche, publiés ou non, émanant des établissements d'enseignement et de recherche français ou étrangers, des laboratoires publics ou privés. 


\title{
New geomorphic criteria on lateral propagation of blind thrust-related fold growth accommodating oblique convergence
}

\author{
by \\ Bernard Delcaillau, Jean-Michel Carozza, Edgard Laville, \\ Mustafa Amrhar, and R. Sheikholeslami
}

with 10 figures

\begin{abstract}
Summary. The aim of this contribution is to show the styles of growing anticlines and the ways in which they accommodate oblique convergence through proximal foreland basins and intramontane basins. The four natural examples of individual fault-related-folds are: the Chandigarh anticline in the Siwalik foothills of Himalaya (NW India), the Pakuashan anticline in the western foothills of Central Range (Taiwan), the J.Bou Dhar-Tamdafelt fold belt (Morocco) and the Marand anticline in the North-Tabriz Fault-Zone (NW Iran). Using a combination of field observations and digital topographic information obtained from satellite imagery, several geomorphic indicators of lateral propagation of folding are: (1) the relief of the topographic profile along the fold hingeline; (2) the development of drainage basins and drainage networks; (3) the elevation of wind gaps and antecedent water gaps, drainage diversion and stream captures that result from growing anticlines; (4) uplift and warping of terrace deposit surfaces as a tool to assess continued deformation. The evolution of these geomorphic criteria and drainage patterns shows evidence of lateral propagation of folds accommodating oblique convergence. This paper focuses on the geomorphic indicators that could be used to provide information on the timing of fault-related folding and direction of lateral propagation. Several tectonic scenarios has been analysed and an attempt has been made to delineate the sequential evolution of anticlines accommodating oblique convergence.
\end{abstract}

Zusammenfassung. Nene geomorphologische Indikatoren zum seitlichen Wachstum aktiver antiklinaler Faltungen in schräg konvergenten Anpassungszonen. - Dieser Beitrag befasst sich mit den Beziehungen zwischen aktiver Faltung und ihrem geomorphologischen Ausdruck in den Piedmonts von Gebirgsketten und in intramontanen Becken, anhand von 4 Beispielen: (1) das J. Bou Dhar-Tamdafelt Faltenbündel (fold belt), Marokko; (2) die Maroud Antiklinale, Nord-Tabriz (NW Iran); (3) die Pakuashan Antiklinale in den Vorbergen der Zentralgebirgskette von Taiwan; (4) die Chandigarh Antiklinale in den Siwaliks (Vorberge des Himalaya, NW Indien). Mittels Geländebeobachtungen, numerischen Geländemodellen und Satellitendaten wurden für die Kinematik des seitlichen Wachstums der Faltungen folgende geomorphologische, hydrographische und sedimentäre Indikatoren benutzt:

- das topographische Profil längs der Faltenachsen

- die Höhenlagen der antezedenten Einschnitte, wind-gaps, die Flussablenkungen und Anzapfungen 
- die Charakteristiken der hydrographischen Einzugsgebiete und Netze

- Morphometrie und Geometrie der sedimentären Ablagerungen (Akkumulationsterrassen und Schwemmfächer) und ihre Verbiegungen.

Hebungsrate und Chronologie der Wachstums- und Zerstörungphasen der Antiklinale konnten ermittelt werden. Verschiedene Wachstumstypen der Antiklinalen wurden so in mehreren konvergenten Faltungszonen durch kritische Betrachtung ihrer physiograpischen Charakteristiken ermittelt.

Résumé. Cet article est une contribution nouvelle sur les relations entre la croissance des plis actifs et leur expression géomorphologique dans les piémonts de chaines et dans les bassins intramontagneux. Les 4 exemples choisis sont: le J. Bou Dhar-Tamdafelt fold belt (Morocco), le pli de Marand dans la zone de faille de Tabriz (NW Iran), l'anticlinal de Chandigarh (piémont Siwalik de Himalaya, NW de l'Inde) et l'anticlinal de Pakuashan (piémont de la Chaîne Centrale, Taiwan). La propagation latérale des plis est enregistrée par un ensemble de marqueurs morphologiques, hydrographiques et sédimentaires. Les images satellitaires et les modèles numériques de terrain confirmés ou infirmés par les données de terrain sont utilisés de façon optimale pour une meilleure connaissance de la cinématique de ces rides anticlinales jeunes. Les variables morphométriques et la géométrie des dépôts quaternaires ont permis d'évaluer les taux de surrection des reliefs et le timing des phases de croissance et de dégradation de ces anticlinaux. Plusieurs schémas d'évolution de croissance des plis dans plusieurs zones de convergence à composante latérale sont ici présentés.

\section{Introduction}

The late Neogene deformation of orogenic wedges appears to be dominated by thrustrelated folds along the piedmonts of foreland basins (Burbank \& Anderson 2000, Delcaillau 2004). The spectacular geomorphic features are related to anticlinal ramps and blind thrusts. Recent studies of tectonic geomorphology and syntectonic sediments (growth strata) have focused on frontal folds in tectonically active mountain belts (e.g. Medwedeff 1992, Whipple 2004, Bernal et al. 2004, Dorsey $\&$ Roering 2005). Anticlines ridges described in foothills ranges have been interpreted as a result of a still active thin-skinned tectonic. Geological and geomorphic features are sensitive to active buried thrust-faults: topographic relief, the geometry of geomorphic surfaces, drainage pattern and thickness of growth deposits (e.g. DeLcaillau et al. 1998, Holbrook \& Schumm 1999, Champel et al. 2002, Burrato et al. 2003). Blind thrust faults are accommodated as folding that develops asymmetric ridges on rectilinear scarps on the forelimb side. In this paper three basic questions are addressed: (1) what are the parameters controlling the genesis of anticlines produced by oblique convergence pattern?; (2) what are the kinematics of fold propagation during transfer zone development?; (3) what are the geomorphic criteria showing evidence of lateral propagation of anticlines?. We investigate anticline ridges which grow inward and laterally in foreland basins and intermontane basins. To follow the morphological scenario during the folding process, we relied on thrusting structures, drainage pattern and Quaternary sedimentary bodies as reference surfaces. We examine the morphology of anticlines by combining satellite image interpretation (Landsat TM), Digital Elevation Model, geological maps and field observations. Morever, we use morphometric data in order to underline the timing of the growing fold and the propagation of the deformation. DEM data used for this work result from Shut- 
tle Radar Topographic Missions (SRTM). We recognize growing fault-related folds accommodating oblique convergence as recorded by their geomorphic criteria: (1) relief of the topographic profile along the fold crest; (2) development of drainage basins and drainage networks; stream long profiles and fluvial terrace profiles are used to determine variations in the rate of uplift and in the style of folding; (3) elevation of wind gaps and antecedent water gaps; (4) uplift and deformation of terrace deposit surfaces, surveyed along river valleys, as a tool to assess continued folding. We apply the criteria to the J. Bou Dhar and the J. Tamdafelt fold zones (Missour basin, Morocco), the north flank of the Tabriz Fault-Zone (NW Iran), the Chandigarh anticline (Siwalik foothills, NW India) and Pakuashan anticline (western foothills of Taiwan).

\section{Classification and geomorphic indicators of growing folds}

In active thrust belts, geometrical relationships between folding and thrusting have been recognized (Suppe 1983, Jamison 1987, Dahlstrom 1990). Thin-skinned thrust belts consist of a decollement, and imbricate thrusts that branch off from the basal thrust. The fold style can be interpreted as purely thin-skinned deformation within synorogenic sediments. The fault-related folds, which are the basic deformation styles of the foreland thrust wedge, are classified into following kinds (fig. 1A): (i) detachment folds where folds develop above a basal decollement (DAHLSTROM 1990); (ii) fault-bend folds where strata deform over bends in a pre-existing fault (e. g. Suppe 1983); (iii) fault-propagation folds where strata deform in advance of a growing thrust-fault tip (e.g. Suppe \& MedwedefF 1990); (iv) wedge thrust-fold; (v) boxshaped folds into an A-shaped structure; the hinge of this fold has a flat top and two steep limbs; (vi) duplex or antiformal stack (ElliotT \& JoHnson 1980). The composite anticlines or wrinkle anticlines are developed from coalescing of independent segments that grew towards each other (e.g. TATE et al. 2001, Davis et al., in press) (fig. 1b). The folds have fundamentally different folding mechanisms, which reflect in their contrasting geomorphology. Individual folds are typically cylindrical over much of their lengths or conical. In fold-and-thrust belts where thick sedimentary deposits predated the shortening, the preexisting structural architecture control the folding. In many foreland basins, fault-related folds are associated with transfer faults and tear faults (Twiss \& Moore 1992, Medwedeff 1992, Delcaillau et al. 1998). These steep faults connect offset segments of thrusts are anticlinal ridges. The faultrelated folds terminations are lateral ramps, transfer faults and tear faults (WILKERson et al. 2002).

Geomorphic systems are analysed to detect the various responses of landforms and drainage pattern to Late Quaternary anticline growth (Keller et al. 1999). Topography and drainage basin register uplift and are valuable tools to discriminate frontal and lateral propagation of folds (e.g. Jackson et al. 1996; BENEDETTI et al. 2000, Pearce et al. 2004). The relationship between fault geometry, kinematics of the deformation and geomorphology suggests growth models of thrust faults in mountain belts (e.g., WeLls et al. 1988). Several active anticlines are interpreted as lateral growth of fault-related folds recorded by well-preserved geomorphic surfaces and river diversions (e.g. Schumm 1986, Mueller \& Talling 1997, Schumm et al. 2000, VAN DER BEEK et al. 2002). JACKsOn et al. (1996) postulates: that (1) the elevations of wind gaps along an anticline decrease in the direction of propagation and reveal the 


\section{a Unsegmented fault-related anticlines}

(i)

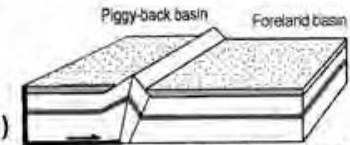

Detachment anticline (South TienShan) (ii)

Fault-bend anticline (North Pakuashan anticline, Taiwan)
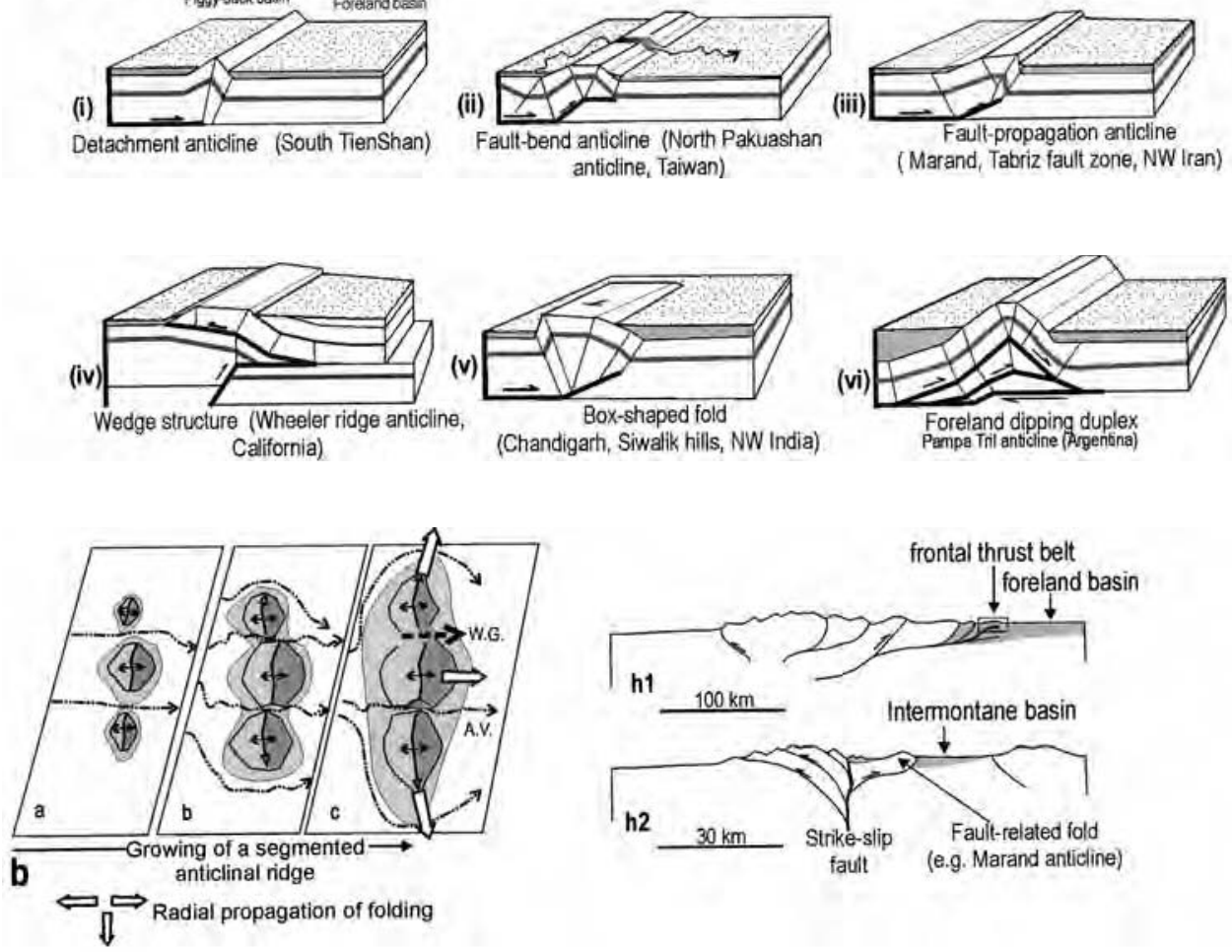

Fig. 1. Schematic diagram showing the development of growing frontal folds. a. unsegmented fault-related anticlines; h1: growing folds in foreland basins (Pakuashan anticline, Taiwan and Chandigarh anticline, NW India); h2: fault-related folds in intermontane basins produced by oblique collision (Bou Dhar-Tamdafelt fold belt in the Missour basin, Morocco and Marand anticline, NW Iran). b. Growing of a segmented fault-related anticline. W. G.: wind gap; A. V.: antecedent valley.

direction of fold plunge; (2) the drainage pattern parallel to an anticline is diverted in the direction of lateral propagation. DelCaIllau et al. (1998) argued that morphometric criteria (relief of the topographic profile, hypsometric integral, drainage density, drainage basins area, longitudinal profiles of streams) demonstrate the growth of folds. In foreland basins, it is useful to define longitudinal river flow parallel to the fold-and-thrust belt and transverse rivers flow orthogonal to the main structures (Delcaillau 1992, Burbank et al. 1996). Transversal rivers are diverted by anticlines and they flow in piggyback basins above frontal hanging wall. Some rivers cutting fold ridges maintain their antecedent course, undeflected across a thrust fault. Antecedent rivers have established a course prior to the growing anticlines and frontal thrust sheet. These rivers have sustained their course across the uplifted fold. Exposed terrace deposits overlapped by buried reverse faults provide evidence of fault evolution propagation (D’Agostino et al. 2001, Delcaillau et al. 2006, Amos et al. 2007). 
2.1 Morphotectonic of the J. Bou Dhar and the J. Tamdafelt area in the Missour basin (southern front of the Middle Atlas, Morocco)

The High Atlas is an ENE-WSW to E-W trending belt about $100 \mathrm{~km}$ wide from which branches the Middle Atlas with a SW-NE trend and about $250 \mathrm{~km}$ length (fig. 2). The southeast boundary of the Folded Middle Atlas corresponds to the South Middle Atlas Fault Zone (SMAFZ). The general convergence direction is NNW-SSE (Morel et al. 1993), which led many authors to propose large strike-slip movements along the NE-SW faults of the High and Middle Atlas (e.g. LAville et al. 2006). In the central Missour basin, the studied area shows a main transfer fault zone trending N-S that connects the South Middle Atlas and the North High Atlas. From North to South, this fault zone is composed of the J. Arhal (Ar), the J. Missour-Tarhirt (MT), the J. Tamdafelt-Chebka ridges (TC) and the J. Chebka (Ch) folds that are en échelon left-stepping minor asymmetrical anticlines with axial direction striking $\mathrm{N} 40^{\circ} \mathrm{E}$ axes trend and $\approx 45^{\circ}$ from fault zone (fig. $2 \mathrm{c}$ ). The axis of J. Missour-Tarhirt (MT) is sigmoidal and its geometry was interpreted as a Jurassic N-dipping normal fault inverted during the Cenozoic (Beauchamp et al. 1996, Gomez et al. 2000, Laville et al. 2006) (fig. 2a). Southwards, J. Tamdafelt-Chebka ridge (TC) consists of exhumed anticlines with a sigmoidal axis. Their axial directions strike from $\mathrm{N} 20^{\circ} \mathrm{E}$ in their southwestern end to $\mathrm{N} 60^{\circ} \mathrm{E}$ in their eastern end (fig. 2c). This narrow zone of folds is manifested in a sinistral transpressive system and conforms to a $\mathrm{N} 150^{\circ}$ E-trending shortening direction. A conjugate dextral zone with en echelon anticlines is located in the western part of the Jebel Arhlal (fig. 2b). Lastest Pliocene sedimentary evolution records a carbonate lacustrine with periodical exundations in the Missour basin (BouAzza et al., in press). This lacustrine surface formed by impounding water behind the anticline ridge is gently folded. These large Pleistocene alluvial fan surfaces are abandoned and incised by drainage networks. A fan remnant preserved with an elevation of $100 \mathrm{~m}$ above the present-day drainage is gently folded (fig. 2b).

Eastward-flowing rivers that cross the folds incise through the Neogene cover (fig. 2d). The exhumed Jebel Arhlal and Tazzarine anticlines show radial and annular drainage patterns superimposed around the fold terminations. In the northern part, several rivers, trending north-south cutting deep V-shaped valleys, are guided or deflected by north-south active strike-slip faults (fig. $2 \mathrm{~d}$ ). Transverse antecedent rivers traverse the Bou Dhar and Tazzarine folds axis and have maintained their original course during the growing anticlines (fig. $2 \mathrm{~d}$ ). Some deflected streams would originally have flowed through adjacent abandonment dry valley. These wind gaps traversing eroded folds suggest a stream system predating uplift of the anticline ridges.

In the southern segment, the Tamdafelt-Chebka ridge (TC) is about $10 \mathrm{~km}$ length and $8 \mathrm{~km}$ width (fig. 2c, 3a). The convex profile represents a dome structure that is composed of Cretaceous calcareous sediments. The dome exhibits NNE-SSW trending en echelon folds that run $\approx 45^{\circ}$ from to the strike-slip fault (fig. $2 \mathrm{c}$ ). The height change across the folds and the asymmetric pattern of drainage incision indicate that the dome is being uplifted. It exhibits different drainage networks which can be divided into three patterns: i) a trellis pattern associated with the flanks of anticlines; ii) an arcuate pattern and annular lineaments in relation to the propagating ends of anticlinal ridges, and iii) a pronounced radial drainage and inflection patterns 

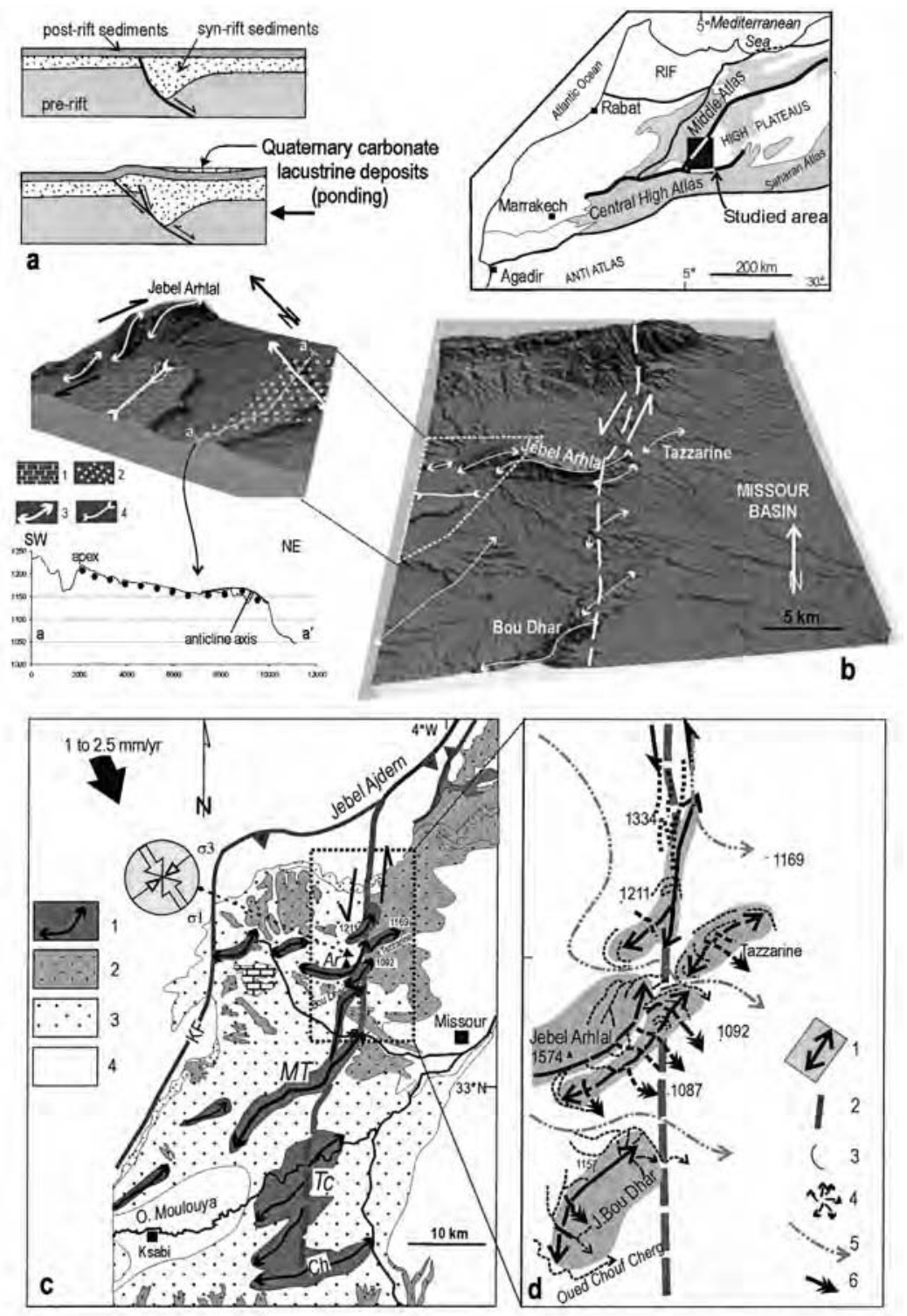

Fig. 2. Relationship between alluvial fans and folds system in the central border of the Missour basin. a: inversion of normal faults and growing of an anticline (adapted from Bump 2003). Schematic figure of the later reactivation of a listric normal fault, creating a footwall shortcut. In the inset, the location of the main structural domains of northern Morocco is indicated; b: DEM of the transfer fault zone and Missour basin; c: Geological and structural map of the western part of the Missour basin (J.Bou Dhar-Tamdafelt area). 1: Jurassic and Cretaceous series; 2: anticline ridges; 3: Pliocene formations; 4: Miocene (Missour basin); 5: alluvium. MT: Missour Tanhit ridge; Ar: Jebel Arhal; TC: Tandafelt-Chebka anticline; Ch: Chebka anticline; KF: Ksabi fault; d: Morphotectonic activity of the J. Bou Dhar 1: active anticlines; 2: fault; 3: deflected river; 4: radial outward drainage network; 5: Transverse antecedent rivers; 6: wind gap talwegs crossing the active sinistral strike-slip fault. 

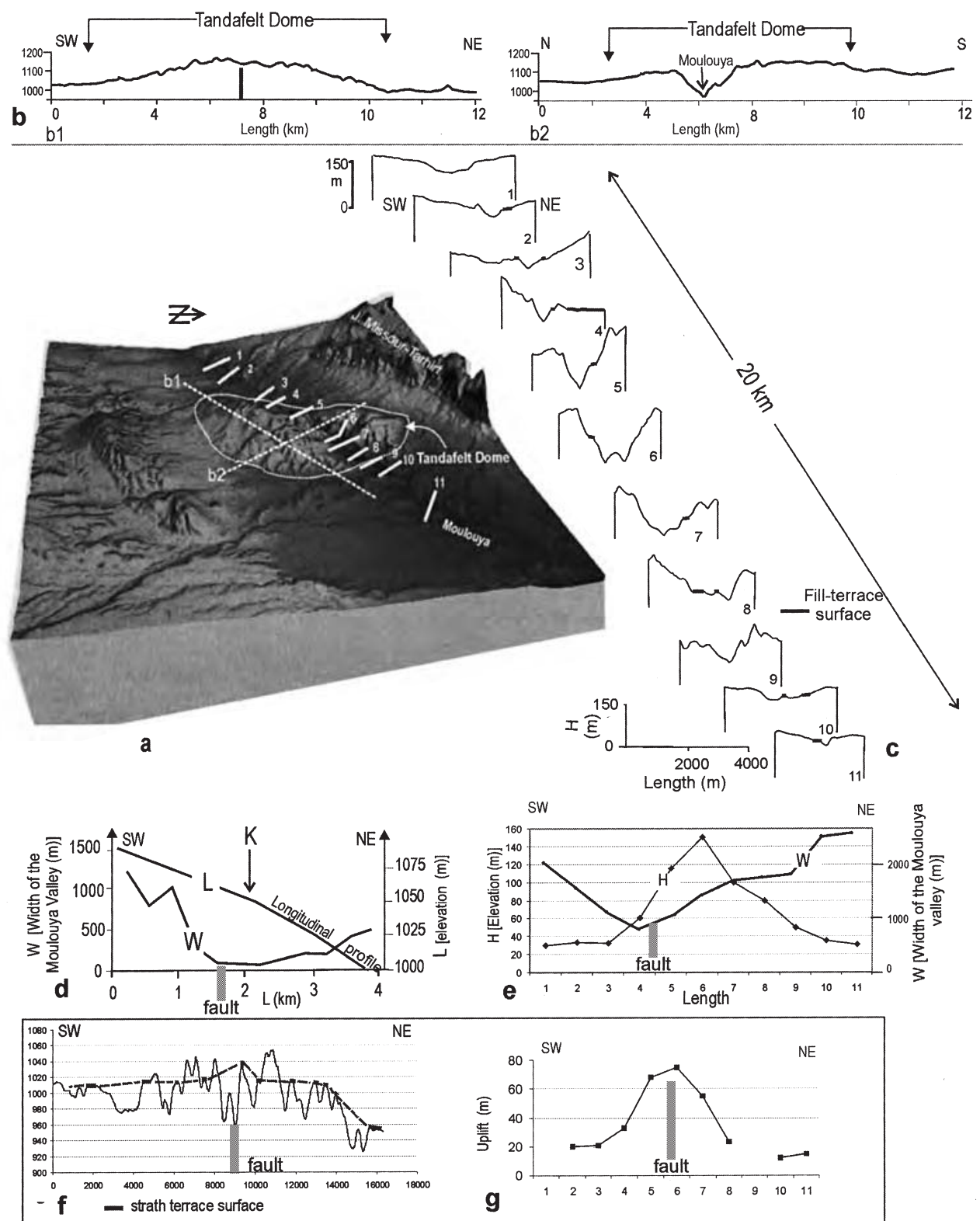

Fig. 3. Morphotectonics of the Tandafelt dome. a: DEM of the Tandafelt dome; b: Topographic cross profiles (location of profiles in fig. $3 \mathrm{a}$ ); c: serial transverse cross sections of the Moulouya valley (location of profiles in fig. 3a); d: Relationship between longitudinal profile $(\mathrm{L})$ and width (W) of the Moulouya valley; $\mathrm{K}$ is the knickpoint that indicates active tectonics; e: Relationship between elevation between top and valley floor $(\mathrm{H})$ and width (W) of the Moulouya valley; f: Topographic cross section in the northern side of the Moulouya valley, projected perpendicular to the strike-slip fault and variation of the tops of the terrace surface; g: Gradient of the perturbed terrace through the Moulouya valley. 


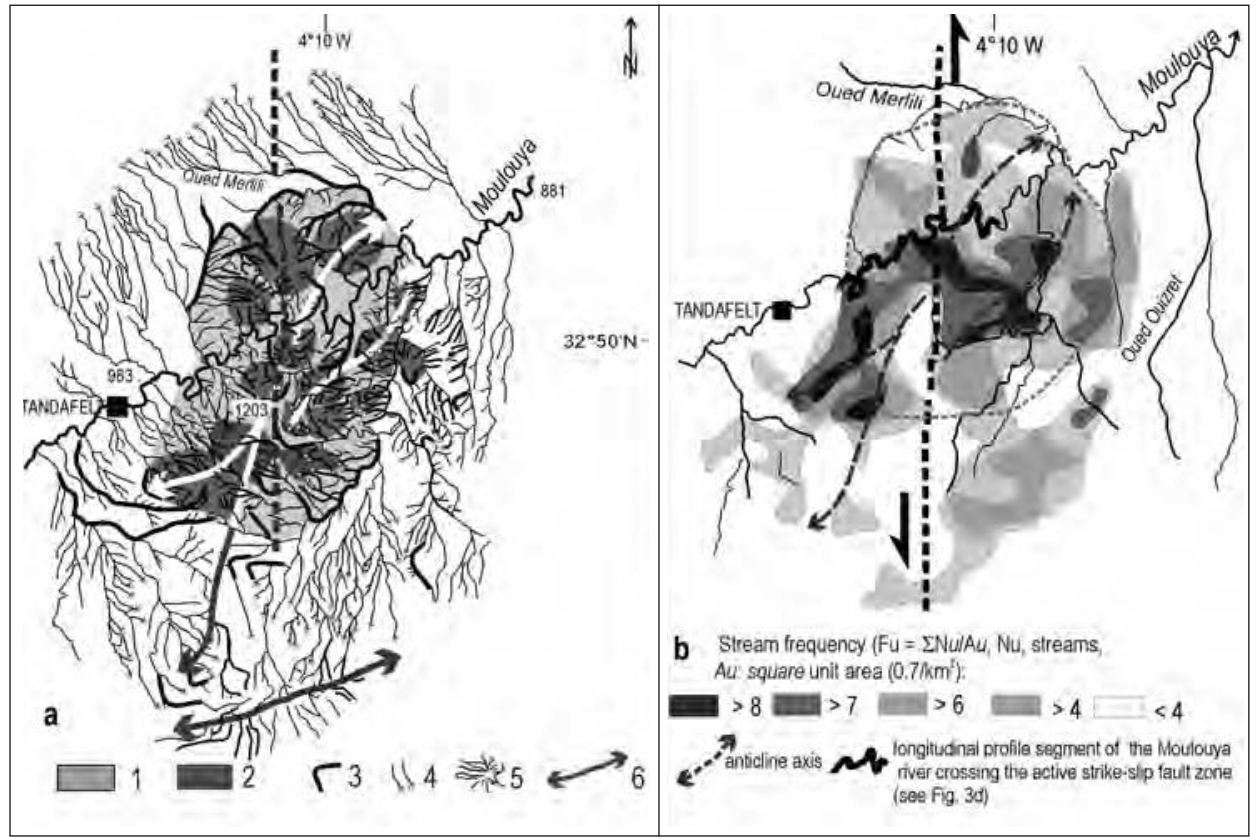

Fig. 4. Drainage pattern of the Tamdafelt dome. a: Drainage network anomalies extracted from hydrographic information from DEM and anomalous streams: 1: Tandafelt dome; 2: Uplifted culminations; 3: deflected river; 4:Headward fluvial erosion; 5: Radial outward drainage network; 6: anticline axis. b: Stream frequency $(\mathrm{Fu}=\Sigma \mathrm{N} u / \mathrm{A} u, \mathrm{Nu}$, streams, $\mathrm{A} u$ : square unit area $\left(0.7 / \mathrm{km}^{2}\right)$, extracted from a $1: 50,000$ scale topographical map.

suggesting recent uplift of ridges producing active push-up structures (fig. 4). The radial drainage networks could indicate uplift of elongated blocks that is located in the north-south active strike-slip fault zone. Segmented ridges are dominated by high-stream frequency ( $>6$ rivers $/ 0.7 \mathrm{~km}^{2}$ ) that record uplift of domes attributing to broad culmination over stepover (fig. 4b). These strong fluvial incisions contrast with adjacent watersheds of low-stream frequency.

The Moulouya river shows a step-like steepening in the channel profile initiated by sudden uplift of the Tamdaleft dome (fig. $3 \mathrm{~d}$ ). The longitudinal profile shows a steep inflection and a convex-down form along Moulouya valley. The knickpoint $(\mathrm{K})$ coincides the main strike-slip fault. It could be attributed to recent uplift movement of the ridge. Morphometric data show marked narrowing of channel widths (W) over the proximal flanks of anticline uplifts toward minimum values well before and after reaching the uplift crest (fig. 3e). Fluvial incision changes in elevation $(\mathrm{H})$ through differential uplift. A long-profile section of the Moulouya Valley shows vertical movement of the mapped principal terrace (fig. $3 \mathrm{f} \& 3 \mathrm{~g}$ ). This terrace is a bedrock strath 30 to $80 \mathrm{~m}$ above modern channel elevation. The fluvial terrace is best preserved along the reaches of the river characterized by a broad valley bottom. Terrace elevations above modern stream channel reflect a folding dating to late Pleistocene after the alluvial filling. 


\subsection{Growth of the Marand anticline (Iranian Azerbaidjan)}

In NW Iran, the principal mountain belts involve major crustal shortening in response to the Arabia-Eurasia collision. The Tabriz region is the continuation of the western Alborz Mountains toward the Caucasus. The North Tabriz fault zone structure is a complex northwest-trending structure that contains evidence of right-lateral strike-slip fault (North Mishu fault and South Mishu faults) (Berberian \& Arshadi 1976). The GPS velocity field indicates a $7 \mathrm{~mm} \cdot \mathrm{yr}^{-1}$ strike-slip motion parallel to the Tabriz fault (Nilforoushan et al. 2003). The North Mishu Fault could be interpreted as a branch of the horse tail termination (fig. 5). Satellite image shows the distinct NW-SE trending Marand fault that is connected to the North Mishu fault $(\mathrm{NMF})$ and ruptured in a earthquake in $1786(\mathrm{M} \approx 6.3)$. In the Mishu fault zone, thrust faults and anticlines are associated with transpression along the Marand Fault (fig. 5). Two geomorphic domains are recognized: (i) en echelon folds in the northern NMF with the Marand anticline in the western part of the fold zone (fig. 5); (ii) a footwall basin in front of the structure with low-gradient streams and coalesced fans (fig. 6a).

The Marand anticline, $15 \mathrm{~km}$ long, runs parallel to the NMF horse tail pattern. Satellite imagery clearly shows the main topographic features of the fold: the drainage

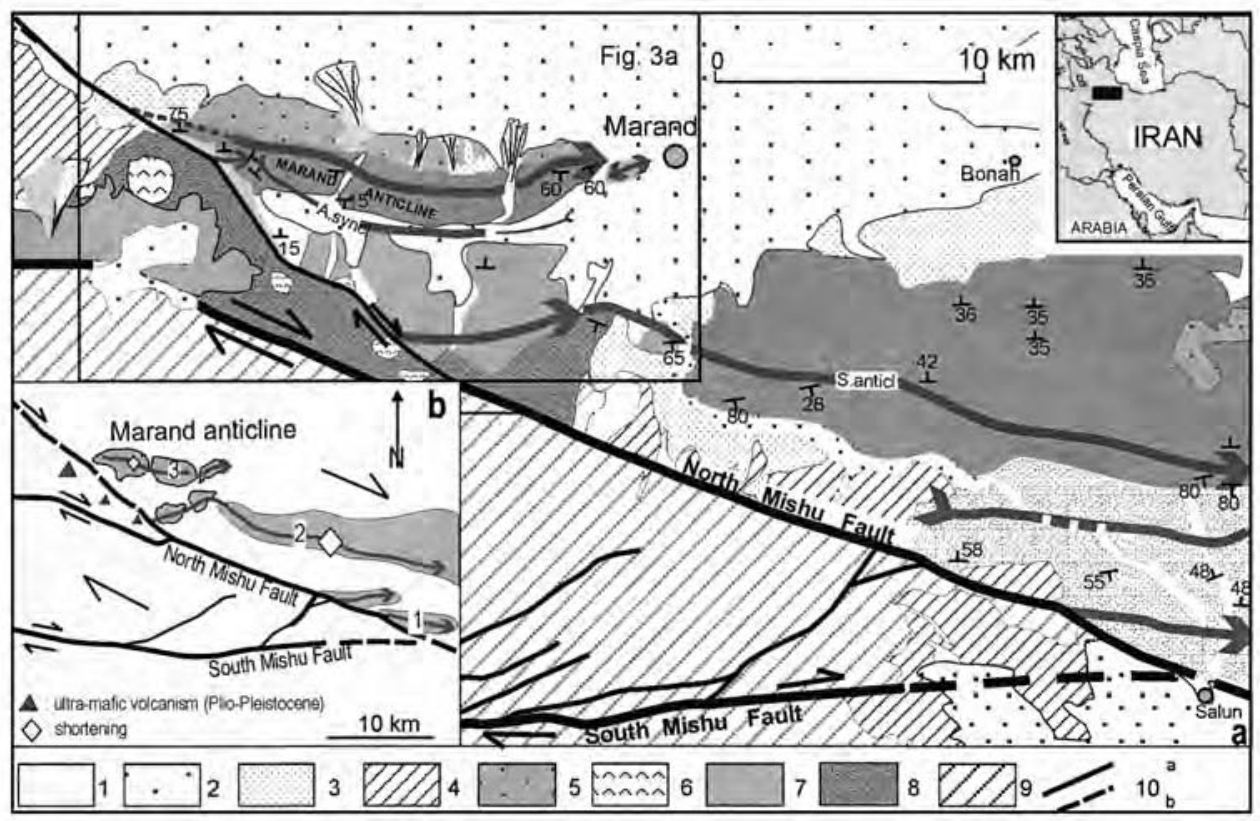

Fig. 5. Geological and morphostructural map of the Marand zone (NW Iran). a. Geological map: 1: Alluvium; 2: Subactual alluvial fan deposits; 3: Intermediate alluvial fan deposits (Qf2); 4: Old alluvial fan deposits (Qf1); 5: terrace deposits (Qt2); 6: Basalte; 7: Pliocene Fm.; 8: Red silts and pelites (Miocene); 9: Cretaceous, Mesozoic and Permian series; 10a: Faults, 10b: Inferred fault. b. Lateral growth of the Marand fault-anticline fold (arrow) and lateral propagation velocities for the frontal fold belt (lozenges). 

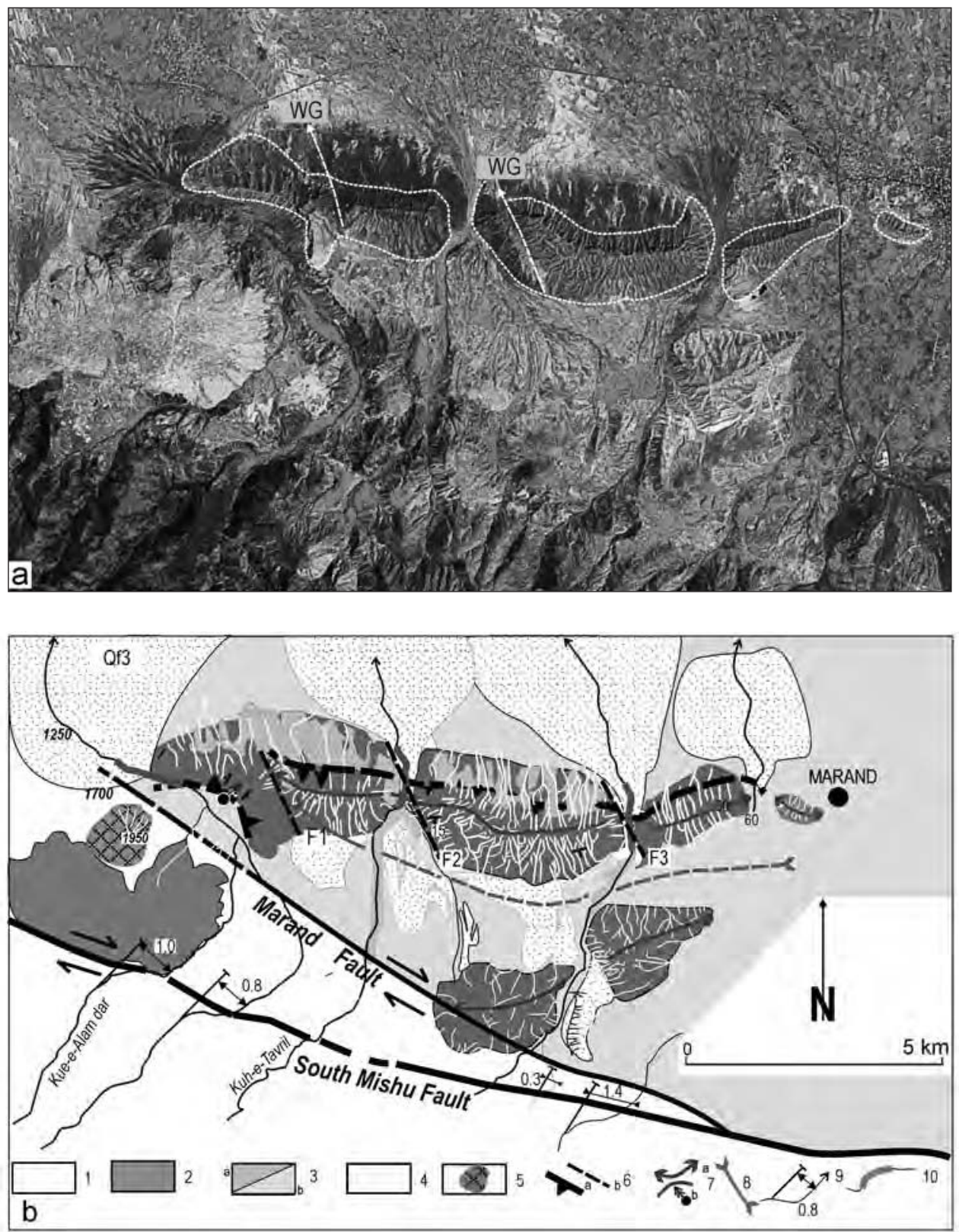

Fig. 6. Morphotectonic scheme and drainage pattern of the Marand anticline. a: Shaded SRTM topography of the Marand anticline ridge; $b$ : Structural pattern and drainage network of the Marand anticline. 1: Miocene formations; 2: Pliocene conglomerates; 3: Pleistocene alluvial fan deposits (Qf2, Qf1); 4: actual alluvium; 5: subactual alluvial fan and strath-terrace deposits; 6: basalt, dacite and trachydacite (Plio-Pleistocene); 7: thrust fault (a) and inferred fault (b); 8a: anticline axis; 8b: conical anticline axis; 9: syncline axis; 10: right-offset of stream; 11: knickzone of river channels. 
network development, the water gaps where palaeodrainage cuts through the growing fold, and the deformed original piedmont surface (Qf2) on the forelimb (fig. 6). From west to east, segment ridges show strike variations in the Marand fold. The hingeline is particularly narrow (fig. $7 \mathrm{~b}$ ). It must be emphasized that this ridge presents an asymmetrical aspect. This elongate ridge is interpreted as a fault-propagation fold above a north-vergent subsurface thrust fault (fig. 6b). Alluvial fan deposits seal the frontal thrust. In its western terminal ending, the thrust is relayed with an other southward verging fold-thrust (fig. 5). Based on satellite imagery, the Marand anticline is formed by five segments (S1, S2, S3, S4 and S5, fig. $7 \mathrm{a}-\mathrm{c}$ ) which branch and relay on transfer faults (F1, F2 \& F3 in fig. 6b). The ridge is segmented and could be considered as a wrinkle ridge typically interpreted as fault-related folds formed above both of blind and emergent thrust-faults.

The drainage along the Kuh-e-Alam dar river has been offset $0.8-1.0 \mathrm{~km}$ in a dextral manner, along a narrow linear gorge crossing the NMF (fig. 6). Two rivers flow northward and cut across the Marand fold. We observe that the westward deviation of the Kuh-e-Alam dar river course is controlled by an increase of the local slope from east to the west and the growing Marand ridge. Based on diversion of recent rivers around the anticline, the folding migrates westward in the western part and eastward in the eastern part. The longitudinal profiles of rivers that across the anticline show downstream variations. The profiles of river segments that cut the anticline ridge are convex (fig. $7 \mathrm{~d}$ ). The river profiles cannot re-establish equilibrium and indicate the active growth of the fold.

Remnants of several wind gaps are preserved in the central and western part of the Marand anticline (WG in fig. 6a \& 7a). On axial culmination of the anticline, these two wind gaps show transverse palaeo-rivers that cut the ridge. These two suspended dry valleys show relics of a previous drainage network now disconnected and lateral deviations of actual river courses. The preservation of abandoned tributaries hanging across the anticline suggests a continual forcing of drainage around the end of the growing fold segment. The development of wind gaps is clearly related to the uplift of the ridge forcing the diverted streams in the direction of lateral propagation. The Qf2 terrace is a bedrock strath $100 \mathrm{~m}$ under the water gap and $40 \mathrm{~m}$ above the modern channel (fig. $7 \mathrm{~b}-\mathrm{c}$ ). The Pleistocene deposits along the crest indicate stream capture of rivers that are deflected by the growing anticline. The angular unconformity between the low dips of alluvial fan deposits and the fold core indicates that the anticline was actively cut before its isolation from further uplift and fluvial incision.

We interpret the growing Marand as lateral propagation of the deformation that caused increased incision, regressive erosion, headward enlargement of catchments and progressive stream capture. Prominent wind gaps were formed during the Qf2 sedimentation when antecedent streams were deflected, forcing the stream around the nose of the fold. The deformation of the Quaternary terraces suggests recent migration of the forelimb anticline hinge (fig. 7b) as predicted by RAFINI \& MERCIER model (2002). Distinct culminations, bounded by tear faults, suggest that folding have propagated laterally. Whereas the younger anticline (S5) starts to propagate eastwards, the western nose of the S1 reached the Marand fault and is now blocked-up (fig. 7a). 


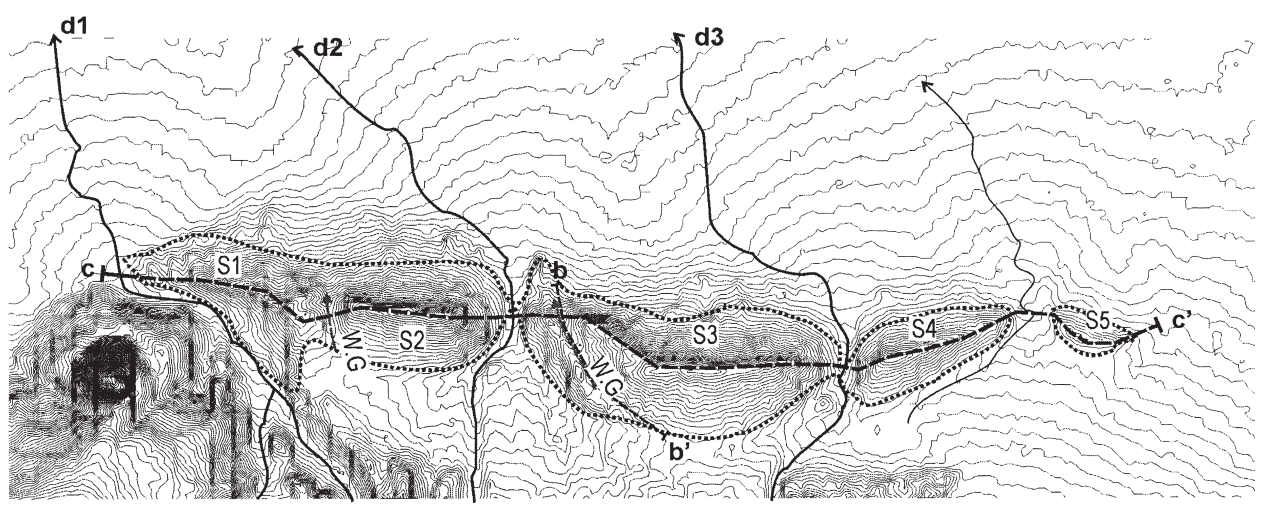

a
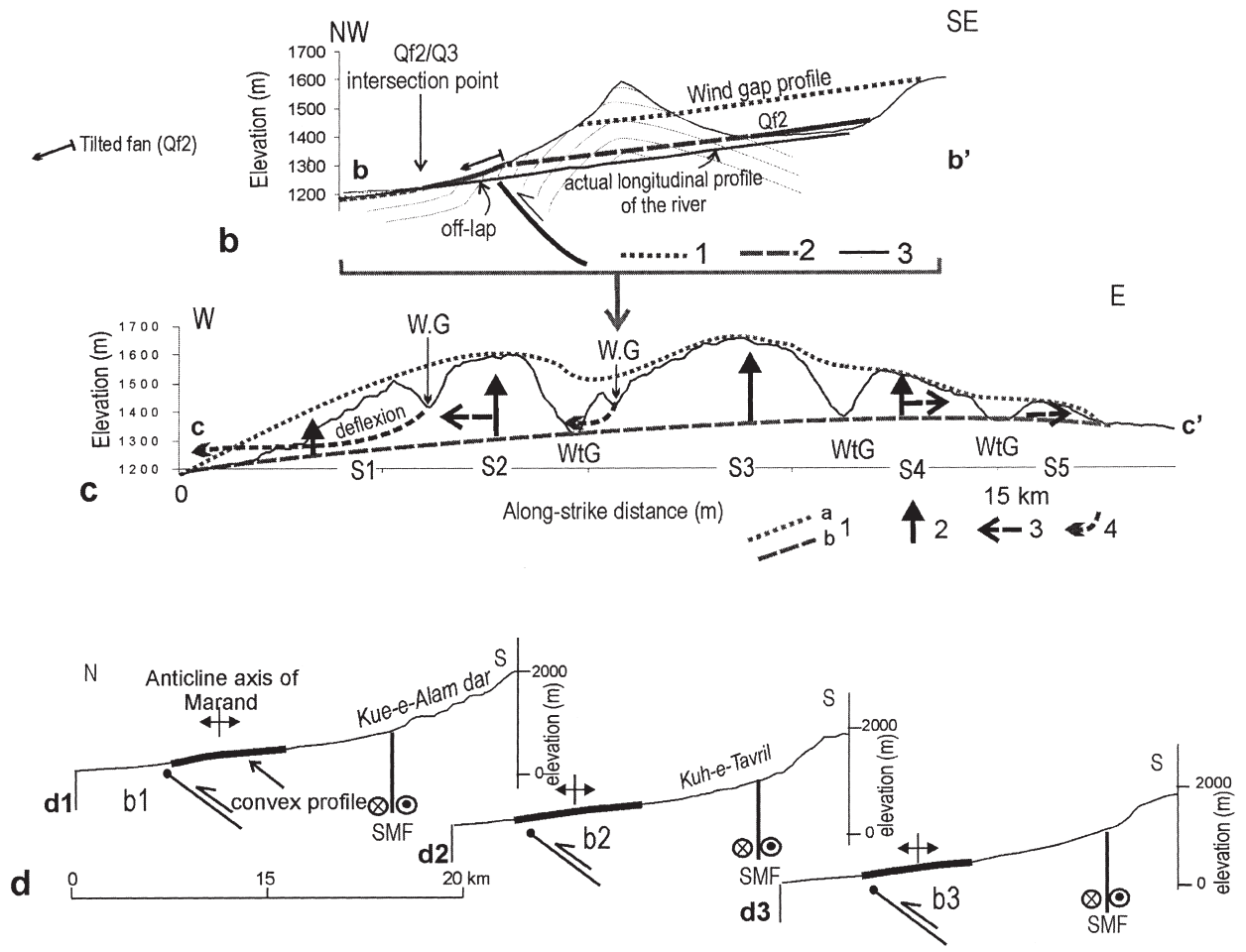

Fig. 7. The geomorphic pattern of the Marand anticline ridge (NW Iran). a: Topographic map and location of cross sections; b: Transversal topographic profile across the fold, and through the wind gap: 1: wing gap profile; 2: Plots of the vertical distribution of the alluvial fan Quaternary deposits along the river $(\mathrm{Q}$ 2) $)$ 3: actual longitudinal profile of the river. c: Topographic profiles crossing the Marand anticline, 1a: Upper topographic enveloping surface of the anticline ridge (top elevation of the ridge); $1 \mathrm{~b}$ : Lower elevation of transversal valleys; 2 : uplift; 3 : lateral propagation of the folding; 4: deflection of rivers. S1, S2, S3, S4 and S5 indicate individual fold-segments; d: Longitudinal profiles of 3 rivers crossing the Marand anticline (location of the longitudinal profiles in fig. 7a). The thick lines indicating knickpoints and convex longitudinal profile show active uplift. NMF: North Mishu Fault. 


\subsection{The Pakuashan anticline (western foothills of Central Range, Taiwan)}

The Taiwan Mountain belt is formed by widespread uplift of the crust due to late Cenozoic oblique collision of the Eurasian plate with the Philippine Sea plate (Ho 1982). At present, the Philippine Sea plate converges with the Eurasian plate a rate of $7.1 \mathrm{~cm} / \mathrm{yr}$ along a $\mathrm{N} 307^{\circ}$ direction (SENO et al. 1993). The Pakuashan ridge is part of a thin-skinned fault system which deforms the upper 2 to $3 \mathrm{~km}$ of the Plio-Pleistocene deposits (fig. 8a). The Changhua Thrust fault has propagated westwards in the thick sequence of Plio-Pleistocene sediments. The Pakuashan anticline, trending $\mathrm{N} 150 \mathrm{E}$ to $\mathrm{N} \mathrm{000,} \mathrm{has} \mathrm{been} \mathrm{active} \mathrm{throughout} \mathrm{the} \mathrm{Quaternary} \mathrm{period} \mathrm{(Delcaillau}$ et al. 1998). The Pakuashan ridge is about $32 \mathrm{~km}$ long and up to $5-10 \mathrm{~km}$ wide, with summit elevations reaching $440 \mathrm{~m}$ above the coastal plain. Studies mostly based on balanced cross sections have suggested various amounts of total shortening varying from $400 \mathrm{~m}$ to $5 \mathrm{~km}$ (Mouthereau et al. 1999, Suppe et al. 2004).

The ridge is mainly composed of the Toukoshan Formation, which constitutes the Pleistocene deposits. These conglomerate and sandstones deposits are unconformably by lateritized gravel terraces. This lateritic tableland is the remnant of the oldest alluvial fan and locally fractured (fig. 8b). In the southern part, the raised weathered terrace is preserved on the east limb and on the hinge zone of the anticline (fig. $8 \mathrm{~b} \mathrm{\&} \mathrm{c).}$

The anticline ridge shows an increase in structural relief from north to south and separated different folding styles. The gentle northern and straight southern ramps are connected by the steep central ramp (Sung \& Chen 2004). The Changhua Thrust does not outcrop along the northwestern edge of the anticline. The fold is wide and shows a flat top, with its east and west limbs dipping gently. The surface geology and morphology display the distinctive geometric characteristics of simple-shear faultbend folds which are formed above thrust ramps (Delcaillau et al. 1998, Suppe et al. 2004), (fig. 8).

In the central area, the ridge is symmetrical and narrower (fig. 8-g1). The trend of the fold axis changes from N-S in the central portion to NW-SE in the southern area. In contrast to the E-W-striking mean slope of the two limbs, rivers follow a NW-SE pattern (fig. 8f). This deviation of contorted rivers is attributed to rapid uplift of the central culmination. This segment is controlling by NW-SE trending faults within a zone of simple shear.

In the southern part, the ridge also shows a roughly north-south trending anticline with a narrower forelimb and a broader backlimb. The geometry of the southern ridge is that of a western-vergent, southward plunging anticline with a steep, west-dipping front limb and a broader, more shallowly-inclined back limb (fig. 8-g3). The ridge is interpreted to be a fault-propagation fold, in which displacement is transferred along an emergent east-dipping thrust which is exposed along the length of the front limb (fig. 8-b2). An emergent thrust fault is exposed along the front limb that accommodates shortening. The west-facing front limb morphology is characterized by an over-steepened base and triangular talus facets which are geomorphic features related to dissection of an active fault scarp. Steps in surface topography evident on DEMs define numerous steeply-dipping ESE-WNW and ENE-WSW-trending faults which delimit fault blocks (fig. 8-b-e). The nearly east-west trending scarps are normal faults with downthrows to the south or to the north. The lateritized gravel 

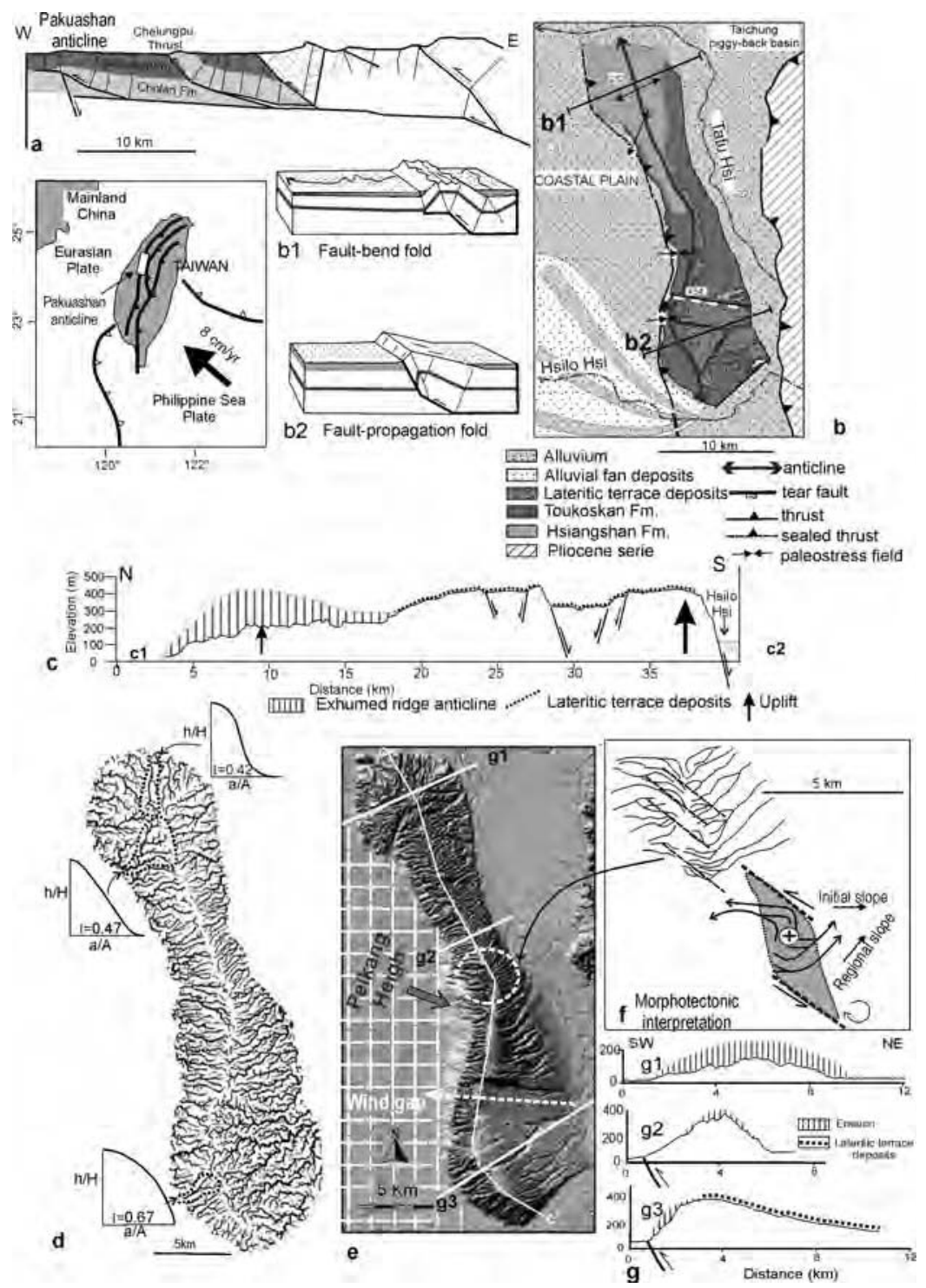

Fig. 8. Morphotectonics of the Pakuashan anticline (western foothills of Taiwan). a: Geological cross section of the western foothills of Taiwan (adapted from Lai et al. 2006); b: Geological map of the Pakuashan anticline; c: Schematic longitudinal topographic cross-section of the Pakuashan ridge (adapted from Delcaillau et al. 1998); Note the flattened graben of the topography within the hingeline; $d$ : Drainage network extracted from hypsometry from $1: 50,000$ scale topographic map. Note hypsometry of the northern drainage basins (concaveconvex form and $\mathrm{I}<0.45$ ) that differ from those of the southern watershed (concave-down form and I $>0.60)$; e: Pakuashan anticline from a DEM obtained from stereoscopic SPOT panchromatic images; $\mathrm{f}$ : Anomalous drainage networks in the central part of the ridge and morphotectonic interpretation; g: Topographic cross-sections of the anticline ridge. From North to South, the asymmetry of the ridge increases. 
terrace is faulted by transverse faults revealed by morphological analysis (fig. 8c). The throw of the normal fault decreases away from both parts of the fold axis, suggesting a tectonic event synchronous with the growing anticline.

Stream incision propagates upstream perpendicularly to anticline axis and individualize deeply incised, arborescent valley networks (fig. $8 \mathrm{~d}$ ). In the southern part of the anticline, knickpoints along channels cut the western scarp. On the forelimb, the relief ratio, the drainage density and the stream frequency are greater than on the back side (Delcaillau et al. 1998). The hypsometric value is related to the degree of drainage basin maturity and growth of the anticline (fig. $8 \mathrm{~d}$ ). The hypsometric integral can be calculated from the area under the curve, and expresses, as a percentage, the volume of the original drainage basin. The hypsometry of the northern drainage basins (concave-convex form and $\mathrm{I}<0.45$ ) differ from those of the southern watershed (concave-down form and $\mathrm{I}>0.60$ ). Based on geomorphic parameters, such as drainage patterns, the northern ridge could achieve a stationary equilibrium state as opposed to the southern fold segment that is subjected to short-term uplift. Thus, the hypsometric analysis expresses the southward propagation of the anticline.

The sigmoidal shape in the Pakuashan area shows that the anticline and transverse tear-faults have recorded left-lateral movements associated with the east-west shortening. The lateral growing anticline results from the indentation of the Peikang High block (fig. 8e), (DefFontaines et al. 1994, Lu 1995). This passive indentation appears with thrusting wedges in the northern area Pakuashan anticline and transtensional faults in the southern area. The southward migration of the compressive deformation is characterized by the increasing amplitude of the fold. Based on the age of geomorphic surfaces and several deformed strata, Simoes et al. (2005) estimate the age of initiation of folding between $19,000 \mathrm{yr}$ to $300,000 \mathrm{yr}$ and the slip rate on the Changhua blind thrust to $15.9+/-1.4 \mathrm{~mm} / \mathrm{yr}$. The morphological evolution thus varies along the main west-facing scarp as a result of the southward thrusting propagation. The southern tip of the fold anticline has propagated by $32 \mathrm{~km}$ during the $500 \mathrm{ka}$ (Delcaillau et al. 1998). Geomorphic evaluation at Pakuashan anticline reveals that the rate of lateral propagation of the fold is $\approx 80 \mathrm{~m} / \mathrm{ky}$, which is 11 times greater than the vertical uplift rate (10 times for the Wheeler Ridge, KeLLER et al. 1998).

\subsection{The Chandigarh anticline (NW India)}

In the foothills of Himalaya, the growing anticlines and Himalayan Frontal Thrust (HFT) take up a significant part of the convergence (e.g. Delcaillau 1992, Lavé \& Avouac 2000, Mugnier et al. 2005). The Sub-Himalayan foreland basin comprises the Neogene Siwalik Group. Across the northern edge of the foreland basin, the HFT ou called Nalagarh Thrust (Mukhopadhyay \& Premanand 2005), separating the Siwalik foothills and the Indo-Gangetic plain, is a southwest-vergent thrust fault. Rising anticline ridges of synorogenic Siwaliks deposits are separated from the main range front by longitudinal tectonic depressions called dun valleys. The foothills are characterized by regional curvatures of the deformation front which deviates from the general trend of thrust units of the Sub-Himalaya (Powers et al. 1998). The Chandigarh anticline is considered to be one of the most active structures of the Himalayan front (MaLIK \& NAKATA 2003). 
The NW trending Chandigarh ridge is about $50 \mathrm{~km}$ long and up $6-10 \mathrm{~km}$ wide, with summit elevations reaching $600 \mathrm{~m}$ above the Gangetic plain (fig. 9). Streams draining the frontal flank are deeply incised into Upper Siwaliks conglomerates bedrock. The rivers trend NE-SW cutting deep V-shaped valleys. In contrast, streams draining the northeast-facing backlimb are short (mean length $\approx 2 \mathrm{~km}$ ). The width of the frontal flank is about 5 to 10 times larger than the backlimb. The divide is located several kilometres behind the fold axis and has retreated significantly into the backlimb of the active anticline (fig. 9d). From satellite imagery, the presence of a long and straight northeast-facing topographic scarp outlines a strong asymmetry of the boxfold induced by the frontal thrust and probably conjugate to a backthrust (DeLCAILLAU et al. 2006). This backthrust could be connected underneath to the forethrust (fig. 9c). The backlimb is characterized by $3^{\text {rd }}$ and $2^{\text {nd }}$ order small catchments while $4^{\text {th }}$ order catchments distinguish the southwestern flank. In each southwestern drainage basin, the drainage pattern is characterized by small tributaries perpendicular to the main streams, which erode more vigorously on the northwestern side of valley than on the southeast. Asymmetry Factors (AF from Cox 1994) generally show a uniform trend, and have a similar direction and high values $(\mathrm{AF}=70-80)$ (Delcaillau et al. 2006). River channels are affected by lateral tilting by migrating downtilt and by stream captures (fig. $8 \mathrm{f}$ ). Tilting of the ridge and the consequent channel shift down-dip cause asymmetry of the stream network development. Topography relief produced by long-term folding forms hogbacks composed of resistant conglomerates that deflect drainage networks (fig. 8e). This implies that rivers have migrated uniformly to the southeast. The stream system must have started from northwest to the southeast, as is still seen today. The geomorphic expression of long-term folding is indicated by the right-stepping Chandigarh anticline accommodating oblique convergence that will be discussed below.

\section{Discussion}

By using geomorphic parameters, we demonstrate that morphological data and drainage patterns can reveal fold growth. Results of investigations into topographic variations and drainage network indicate radial propagation of frontal anticlines during the Plio-Quaternary. Drainage deflections are interpreted as the result of lateral increases in anticline length. Young alluvial fans deposited across the anticlines are uplifted and deformed. In this paper, the four studied anticlines have their own special character. The propagation of these anticlines is accompanied by accommodation of tear faults and rotation of the fold axis. Accumulation of displacement on faults is commonly accompanied by lateral propagation of normal faults (MOREwOOD \& RoberTs 2002) and fault-and-thrusts (Burbank \& Anderson 2000). Several tectonic scenarios has been analysed and an attempt has been made to delineate the sequential evolution of anticlines accommodating oblique convergence during the Quaternary (fig. 10):

- Accommodation by lateral propagation and tear faults parallel to the main shortening axis (fig. 10a-b). The Wheeler Ridge is an east-west-trending anticline that is actively deforming on a thrust-fault (Mueller \& TAlling 1997, Cowie \& RoberTs 2001) (fig. 10a). Geomorphic analysis and the geometry of Quaternary surfaces are used to determine the rate of uplift associated with the eastward growth of the anti- 

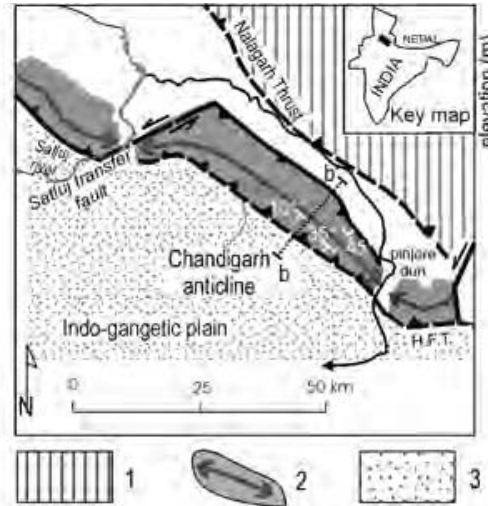

a

d
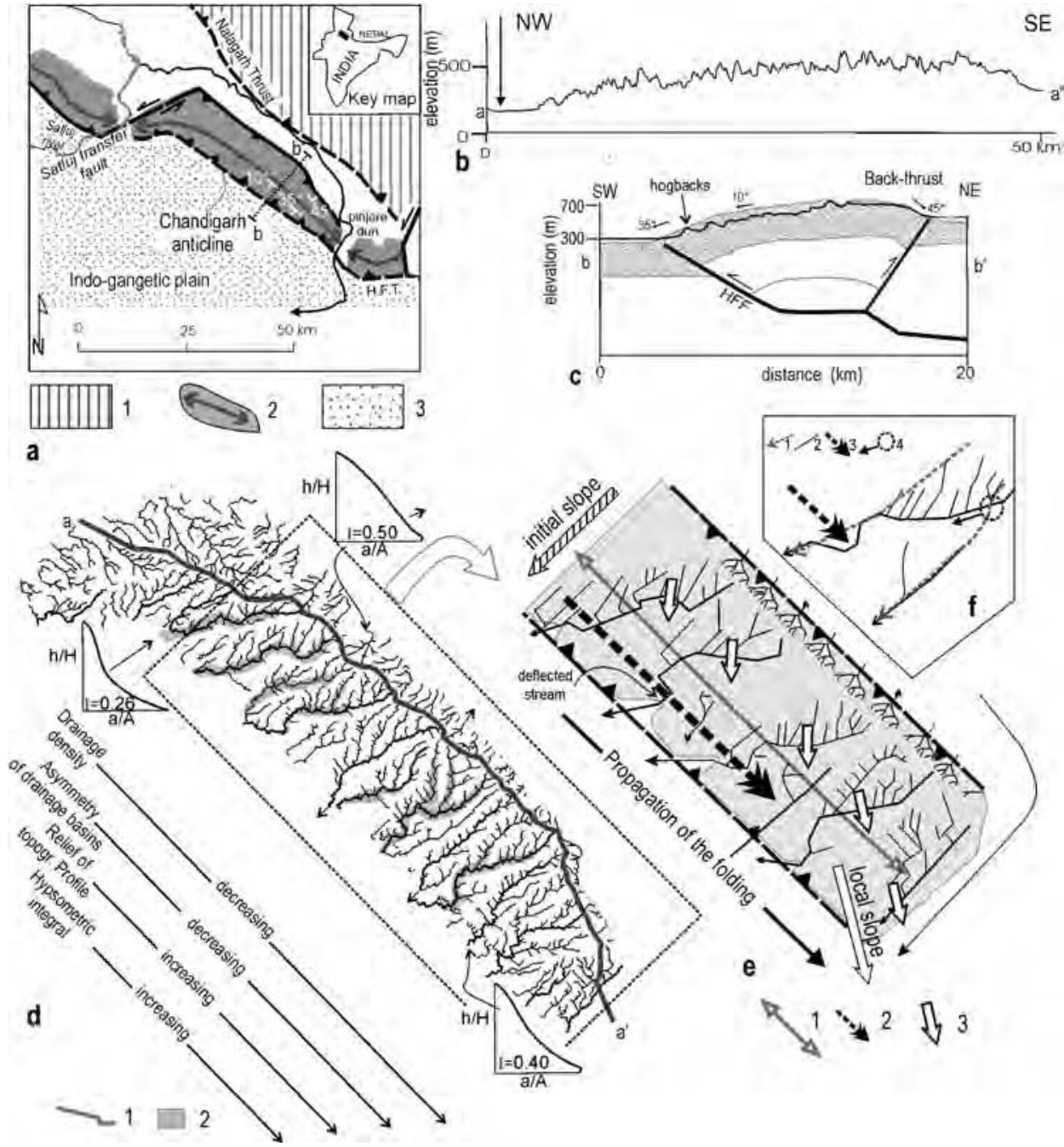

SE

Fig. 9. Structural pattern and drainage network of the Chandigarh anticline (NW India, Siwalik front). a: Structural pattern of the Chandigarh area: 1: lower Siwaliks sandstones; 2: Chandigarh ridge anticline; 3: Alluvium in Indo-Gangetic plain; H. F. T.: Himalayan Frontal Thrust. b: longitudinal summit elevation profiles along the ridge crest (location in fig. 9d); c: structural cross-section of the anticline (location in fig. 9a); $d$ : drainage map of the Chandigarh ridge: 1 : ridge crest; 2: alluvium; e: Scheme of asymmetric drainage pattern: 1:anticline axis; 2: hogbacks (resistant gravel beds of Upper Siwaliks conglomerates); 3: drainage-basin asymmetry vector (Delcaillau et al. 2006). Note a northeastward headward fluvial erosion. f: captures; 1 : river channel developed on the initial slope; 2: consequent flowing directly down a newly created slope and right-lateral offset of valleys; 3 : lateral propagation of the anticline and hogbacks; 4 : stream capture. 
TOPOGRAPHIC PROFILES ALONG AXIS OF ANTICLINES

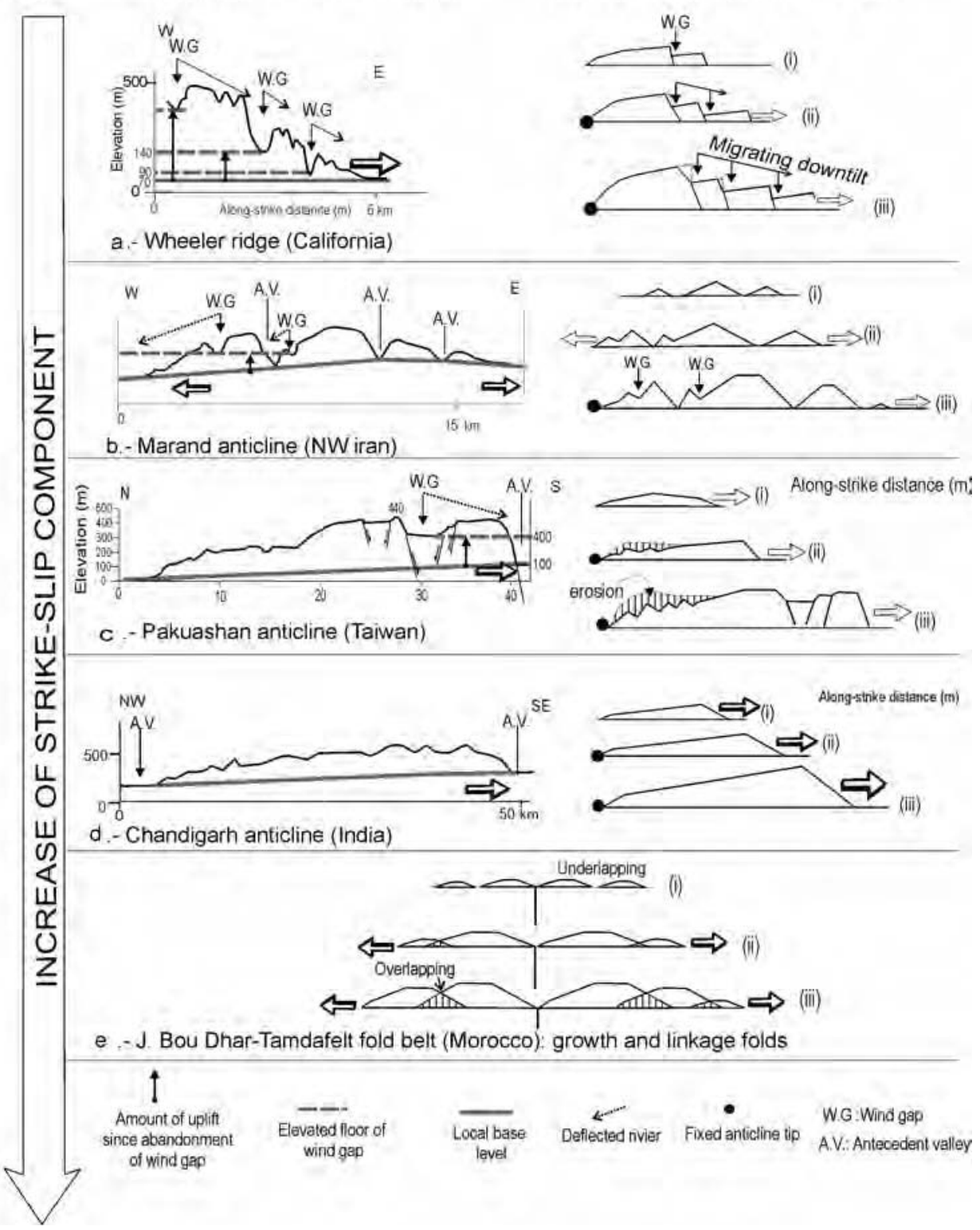

AGGREGATE DISPLACEMENT PROFILES 
cline. Distinct topographic areas are bounded by tear faults and suggest that folding is propagating eastward at a rate about $30 \mathrm{~mm} / \mathrm{yr}$ (KeLLER et al. 1998). A Quaternary tear fault zone accommodates the southward motion of the Changhua Thrust and the Pakuashan anticline anticline developed over an oblique feature of a inherited margin basement (Deffontaines et al. 1997, Delcaillau et al. 1998, Sung \& Chen 2004) (fig. 10c). When the westward propagation of the frontal thrust moved along the northern boundary of the Peikang basement high, tear faulting in the hanging wall were developed. As opposed to the Wheeler ridge, the Pakuashan topographic relief decreases with the age of the growing ridge. Lateral migration of tear faults is clearly defined by the laterally displaced antecedent and uplifted stream segments. The kinematic analysis of the deformation shows that the Pakuashan anticline and transverse tear-faults have recorded left-lateral movements associated with the ESE-WNW shortening. The shortening of the foothills took place in a piggy-back style in restraining bend of thrust-fault system.

- Accommodation by lateral propagation and radial propagation and linkage of en echelon composite anticline. The geomorphic expression of long-term folding indicates that the Marand fold-ridges have propagated radial laterally in the North Mishu Fault horse tail pattern (fig. 10b). At beginning (Stage 1), growth is characterized by individual folds. During stage 2, throw rates increase in the central zone. Further, interaction and linkage of individual fold-segments occur (Stage 3). The folding could be accommodated in various structural compartments in the hanging wall of the thrust ramp.

- Accommodation by lateral propagation and growing of a box-shaped fold (fig. 10d). The presence of a long and straight northeast-facing topographic scarp indicates an active steeply-dipping thrust-fault and a strong asymmetry of the ridge. The southwestern forelimb of the NW trending Chandigarh ridge has a marked asymmetric drainage basin. Progressive tilting of the anticline and rivers shift downdip cause asymmetry of the stream pattern. We suggest that stream valleys respond to the local slope change and right-lateral offset of valleys in the Chandigarh ridge originally proposed by Delcaillau et al. (1998). This implies that rivers have migrated uniformly and largely to the southeast. The stream system must have started from northwest to the southeast, as is still seen today. We attribute these anomalies of the stream system to a propagation of the folding anticline to the southeast.

- Accommodation by en-echelon folds above a basement wrench fault. The Jebel Arhal and the J. Tamdafelt-Chebka ridges anticlines are left-stepping minor asymmetrical anticlines (fig. 10e). This narrow zone of folds is manifested in a sinistral transpressive system and conforms to a $\mathrm{N} 150^{\circ} \mathrm{E}$-trending shortening direction. The geomorphological observations indicate that these ridges have propagated "out of sequence" over the transfer strike-slip fault. Shortening across these anticlines and transpressional uplifts reduce to the ends, suggesting that antiformal initiation is variable across the structure due to lateral propagation of the deformation.

\section{Conclusion}

We have attempted to show how topography relief, active tectonics and drainage pattern can be used to provide a unified picture of the Quaternary development of four active fold zones. In this paper, field data and DEM's indicate Plio-Quaternary tec- 
tonics to account for the anticlines and thrusts described. The styles of active folding show considerable variations across frontal zones. Four modern examples of growing anticlines display both deflected rivers and persistent antecedent rivers in relationships with laterally propagating structures. Based on analysis of landforms and drainage patterns, geomorphic parameters allow us to infer growing of the anticlines by oblique movement along active reverse and strike-slip faults. Field observations and digital topographic information obtained from satellite imagery have been employed to study of the forward and lateral growth of active fault-related folds. Subtle geomorphological features and drainage pattern as such lateral stream migration and abandoned wind gaps provide evidence of fault evolution propagation. Indentation of ancient blocks and inversion of previous normal faults control the development of several active fold anticlines. The lateral migration of fault-propagation folds induces the closure of late Neogene intermontane piggy-back basins.

\section{Acknowledgement}

Thanks to Prof. H. Vogt for the German summary.

\section{References}

Amos, C. B., Burbank, D. W., Nobes, D. C. \& Read, S. A. L. (2007): Geomorphic constraints on listric thrust faulting: Implications for active deformation in the Mackenzie Basin, South Island, New Zealand. - J. of Geophys. Res. 112: Issue B3SII.

Beauchamp, W., Barazangi, M., Demnati, A. \& El Alji, M. (1996): Intracontinental rifting and inversion: Missour basin and Atlas mountains, Morocco. - Amer. Assoc. of Petroleum Geol. Bull. 80: 1459-1482.

Benedetti, L., Tapponnier, P., King, G. C. P., Meyer, B. \& Manighetti, I. (2000): Growth folding and active thrusting in the Montello region, Veneto, northern Italy. - J. G. R. 105, NO B1: 739-766.

Berberian, M. \& Arshadi, S. (1976): On the evidence of the youngest activity of the North Tabriz fault and the seismicity of Tabriz city - Geol. Surv. Iran 39:397-418.

Bernal, A., Hardy, S., Gawthorpez, R. \& Finchz, E. (2004): Stratigraphic expression of the lateral propagation and growth of isolated fault-related uplifts. - Basin Res. 16: 219-233.

Bouazza, A., Dugué, O., Catteneo, G., Laville, E., Ait Brahim, L., Charroud, M., DelCaillau, B., De Luca, P. \& Zora, Z. (in press): Neogene sedimentary changes in the Eastern Morocco: the Messinian crisis identification. - C. R. Géosciences, Paris.

Bump, A. P. (2003): Reactivation, trishear modelling, and folded basement in Laramide uplifts: implications for the origins of intracontinental faults. - GSA Today 4-10.

Burbank, D. W. \& Anderson, R. S. (2000): Tectonic Geomorphology. - Blackwell Science: 1-274. Burbank, D. W., Meigs, A. \& Brozovic, N. (1996): Interactions of growing folds and coeval depositional systems. - Basin Res. 8: 199-223.

Burrato, P., Ciucci, R. \& Valensise, G. (2003): An inventory of river anomalies in the Po Plain, Northern Italy: evidence for active blind thrust faulting. - Annals of Geophysics 46,5: 865-882.

ChaI, B. H. T. (1972): Structure and tectonic evolution of Taiwan. - Am. J. Sci. 272: 389-422.

Champel, B., Van Der Beek, P., Mugnier, J. L. \& Leturmy, P. (2002): Growth and lateral propagation of fault-related folds in the Siwaliks of Western Nepal: rates, mechanisms, and geomorphic signature. - J. Geophys. Res. 107 (B6): 10.1029/2001JB000578. 
Cowie, P.A. \& Roberts, G.P.(2001): Constraining slipe rates and spacing for active normal faults. - J. of Struct. Geol. 23: 1901-1915.

Cox, R. T. (1994): Analysis of drainage basin symmetry as a rapid technique to identify areas of possible Quaternary tilt-block tectonics: an example from the Mississippi Embayment. - Geol. Soc. of Amer. Bull. 106: 571-581.

D’Agostino, N., Jackson, J. A., Dramis, F. \& Funiciello, R. (2001): Interactions between mantle upwelling, drainage evolution and active normal faulting: an example from the central Apennines (Italy). - Geophys. J. Int. 147: 475-497.

Dahlstrom, C.D.A. (1990): Geometric constraints derived from the law of conservation of volume and applied to evolutionary models for detachment folding. - Bull. of the Amer. Assoc. of Petroleum Geologists 74: 336-344.

Davis, K., Burbank, D. W., Fisher, D., Wallace, S. \& Nobes, D. (in press): Thrust-fault growth and segment linkage in the active Ostler fault zone, New Zealand. - J. of Struct. Geol.

Deffontaines, B., Lacombe, O., Angelier, J., Chu, H.T., Mouthereau, F., Lee, C. T., Deramond, J., Lee, J. F., Yu, M.S. \& Liew, P. M. (1997): Quaternary transfer faulting in the Taiwan Foothills: evidence from a multisource approach. - Tectonophysics 274: 6182.

Deffontaines, B., Lee, J. C., Angelier, J., Carvalho, J. \& Rudant, J. P. (1994): New geomorphic data on Taiwan active orogen: a multisource approach. - J. Geophys. Res. 99: 20243-20266.

Delcaillau, B. (1992): Les Siwaliks du Népal oriental. - CNRS éditions, Paris, 205 p. (2004): Reliefs et Tectonique récente. - Vuibert, Paris: 1-259.

Delcaillau, B., Carozza, J. M. \& Laville, E. (2006): Recent fold growth and drainage development: the Janauri and Chandigarh anticlines in the Siwalik foothills, Northwest India. - Geomorphology 76: 241-256.

Delcaillau, B., Deffontaines, B., Angelier, J., Déramond, J., Floissac, L., Souquet, P. \& CHU, H. T. (1998): Morphotectonic evidence from lateral propagation of an active frontal fold; the Pakuashan anticline, foothills of Taiwan. - Geomorphology 24: 263290.

Dorsey, R. J. \& Roering, J. J. (2005): Quaternary landscape evolution in the San Jacinto fault zone, Peninsular Ranges of Southern California: Transient response to strike-slip fault initiation. - Geomorphology 73: 16-32.

Elliott, D. \& Johnson, M.R. W. (1980): Structural evolution in the northern part of the Moine thrust belt, NW Scotland. - Transactions of the Royal Society of Edinburgh, Earth Sciences 71: 69-96.

Gomez, F., Beauchamp, W. \& Barazangi, M. (2000): Role of the Atlas mountains (northwest Africa) within the African-Eurasian plate-boundary zone. - Geology 28: 775-778.

Ho, C.S. (1982): Tectonic evolution of Taiwan. Explanatory text of the Tectonic map of Taiwan. - The ministry of Economic Affairs, Republic of China.

Holbrook, J. \& Schumm, S. A. (1999): Geomorphic and sedimentary response of rivers to tectonic deformation: a brief review and critique of a tool for recognizing subtle epirogenic deformation in modern and ancient settings. - Tectonophysics 305: 287-306.

Jackson, J., Norris, R. \& Youngson, J. (1996): The structural evolution of active fault and fold systems in central Otago, $\mathrm{New}$-Zealand: evidence revealed by drainage patterns. J. of Struct. Geol. 18, Nos 2/3: 217-234.

JamisON, W.R. (1987): Geometric analysis of fold development in overthrust terranes. - J. of Struct. Geol. 9: 207-219.

Keller, E. A., Zepeda, R. L., Rockwell, T. K., Ku, T. L. \& Dinklage, W.S. (1998): Active tectonics at Wheeler Ridge, southern San Joaquin Valley, California. - Geol. Soc. of Amer. Bull. 110, 3: 298-310. 
Keller, E. A., Gurrola, L. \& Tierney T.E. (1999): Geomorphic criteria to determine direction of lateral propagation of reverse faulting and folding. - Geology 27, 6: 515-518.

LaI, K. Y., Chen, Y. G., Hung, J. H., Suppe, J., Yue, L. F. \& Chen, Y. W. (2006): Surface deformation related to kink-folding above an active fault: Evidence from geomorphic features and co-seismic slips, Quaternary International. - Quatern. Internat. 147: 44-54.

Lavé, J. \& Avouac, J.P. (2000): Active folding of Fluvial Terraces across the Siwaliks Hills (Himalayas of Central Nepal). - J. Geophys. Res. 105: 5735-5770.

Laville, E., Delcaillau, B., Charroud, M., Dugue, O., Brahim, A., Cattaneo, G., Deluca, P. \& Bouazza, A. (2006): The Plio-Pleistocene evolution of the Southern Middle Atlas Fault Zone (SMAFZ) front of Morocco. - Internat. J. of Earth Sciences. DOI 10.1007

Lu, C. Y. (1995): Oblique convergence and indentation tectonic in the Taiwan mountain belt. Internat. Conf. and $3^{\text {rd }}$ Sino-French Symp. on Active Collision in Taiwan, Program and extended abstracts: $237-242$.

Malik, J. N. \& NaKaTA, T. (2003): Active faults and related Late Quaternary deformation along the Northwestern Himalayan Frontal Zone, India. - Annals of Geophys. 46: 917-936.

MEDWEDEFF, D. A. (1992): Geometry and kinematics of an active, laterally propagating wedge thrust, Wheeler Ridge, California. - In: Mitra, S. \& Fisher, G. W. (eds.): Structural geology of fold and thrust belts. Baltimore, Johns Hopkins University Press: 3-28.

Morel, J., Zouine, M. \& Poisson, A. (1993): Relations entre la subsidence des bassins moulouyens et la création des reliefs atlasiques (Maroc): un exemple d'inversion tectonique depuis le Néogène. - Bull. de la Société géologique de France 164(1): 79-91.

Morewood, N.C. \& RoBerT, G. P. (2002): Surface observations of active normal fault propagation: implications for growth. - J. of Geol. Soc., London 159: 263-272.

Mouthereau, F., Lacombe, O., Deffontaines, B., Angelier, J. \& Chu, H. T. (1999): Quaternary transfer faulting and belt front deformation at Pakuashan (Western Taiwan). Tectonics 18: 215-230.

Mueller, K. \& Talling, P. (1997): Geomorphic evidence for tears faults accommodating lateral propagation of an active fault-bend fold, Wheeler Ridge, California. - J. of Struct. Geol. 19, 3-4: 397-411.

Mugnier, J. L., Huygues, P., Gajurel, A. P. \& Becel, D. (2005): Frontal and piggy-back seismic ruptures in the external thrust belt of Western Nepal. - J. of Asian Earth Sciences 25: 707-717.

Mukhopadhyay, D. K. \& Premanand, M. (2005): Subathu area, Himachal Pradesh, India: thrust sequence, structural evolution and shortening. - J. of Asian Earth Sciences 25: 735-746.

Nilforoushan, F., Masson, F., Vernant, P., Vigny, C., Martinod, J., Abbassi, M., Nankali, H., Hatzfeld, D., Bayer, R., Tavakoli, F., Ashtiani, A., Doerflinger, E., Daignieres, M., Collard, P. \& Chery, J. (2003): GPS network monitors the ArabiaEurasia collision deformation in Iran. - J. of Geodesy 77: 411-422.

Pearce, S. A., Pazzaglia, F. J. \& Eppes, M. C. (2004): Ephemeral stream response to growing folds. - Geol. Soc. of Amer. Bull. 116, 9/10: 1223-1239.

Powers, P. M., Lillie, R. J. \& Yeats, R. S. (1998): Structure and shortening of the Kangra and Dehra Dun reentrants, Sub-Himalaya, India. - GSA Bull. 110(8): 1010-1027.

Rafini, S. \& Mercier, E. (2002): Forward modelling of foreland progressive unconformities. Sedimentary Geol. 146: 75-89.

Schumm, S.A. (1986): Alluvial river response to active tectonics. - In: Active tectonics. National Academy Press, Washington DC: 80-94.

Schumm, S. A., Dumont, J. F. \& Holbrook, J. M. (2000): Active tectonics and alluvial rivers. Cambridge Univ. Press: 1-276.

Seno, T., Stein, S. \& Gripp, A.E. (1993): A model for the motion of the Philippine sea plate consistent with NUVEL-1 and geological data. - J. Geophys. Res. 98: 17941-17948. 
Simoes, M., Avouac, J.P. \& Chen, Y.-G. (2005): Kinematics of shortening and slip rates on the faults across West Central Taiwan, in Geodynamics and Environment in East Asia International Conference \& $5^{\text {th }}$ Taiwan-France Earth Science Symposium, Taitung, Taiwan (R. O. C.), November 24-29 2005.

Sung, O. \& Chen, Y.C. (2004): Geomorphic evidence and kinematic model for quaternary transfer faulting of the Pakuashan anticline, Central Taiwan. - J. of Asian Earth Sciences 24: 389-404.

Suppe, J. (1983): Geometry and kinematics of fault-bend folding. - Am.J. Sci. 283: 684-721.

Suppe, J. \& MedwedefF, D. (1990): Geometry and kinematics of fault-propagation folding. Eclogae Geologicae Helvetiae 83: 409-454.

Suppe, J., Connors, C. D. \& Zhang, Y. (2004): Shear Fault-bend Folding. - In: McClay, K. R. (Ed.): Thrust Tectonics and Petroleum Systems. Amer. Assoc. of Petroleum Geologists Memoirs 82: 303-323.

Tate, A., Mueller, K.J. \& Golombek, M.P. (2001): Geometry and kinematics of wrinkle ridges on Lunae and Solis Plana, Mars: implications for fault/fold growth history. - Lunar and Planetary Science XXXIII.

Twiss, R.J. \& Moores, E.M. (1992): Structural Geology. - W.H. Freeman and Company: $103-113$.

Van Der Beek, P., Champel, B. \& Mugnier, J.L. (2002): Control of detachment dip on frainage development in regions of active fault-propagation folding. - Geol. Soc. of America 30, 5: 471-474.

Wells, S. G., Bullard, T. F., Menges, C. M., Drake, P. G., Karas, P. A., Kelson, K. I., RitTER, J. B. \& WeSLING, J. R. (1988): Regional variations in tectonic geomorphology along a segmented convergent plate boundary, Pacific coast of Costa Rica. - Geomorphology 1, 3: 239-265.

Whipple, K.X. (2004): Bedrock rivers and the geomorphology of active orogens. - Annual Review of Earth and Planetary Sciences 32: 151-185.

Wilkerson, M. S., APOTRIA, T. \& FARID, T. (2002): Interpreting the geologic map expression of contractional fault-related folds terminaisons: lateral/oblique ramps versus displacement gradient. - J. of Struct. Geol. 24: 593-607.

Addresses of the authors: Bernard Delcaillau, Edgard Laville, UMR-CNRS 6143, M2C «Morphodynamique Continentale et Côtière» 24 rue des Tilleuls, 14000 Caen, France. - Jean-Michel Carozza, Université L. Pasteur Faculté de Géographie 3, rue de l'Argonne F-67083 Strasbourg Cedex, France. - Mustafa Amrhar, Département de Géologie, Faculté de Sciences, B. P. 2390, 400, Marrakech, Menara, Morocco. - R. Sheikholeslami, Geological Survey of Iran, Teheran, Iran.

Corresponding author: bernard.delcaillau@unicaen.fr 